\title{
Optimalisasi Penggunaan Obat yang Bijak dalam Keluarga dengan Program Gema Cermat
}

\section{Optimization of Wisely Drugs Use at Family with "Gema Cermat" Program}

\author{
Handri Mursiti ${ }^{1}$, Galau Menanti Embri ${ }^{1}$, Ana Prasanti ${ }^{1}$, Agnez Maysha ${ }^{1}$, Vivin Rosvita ${ }^{1}$, Yusuf Muamar \\ Bashori $^{1}$ dan Yeni Farida ${ }^{2 *}$ \\ ${ }^{1}$ Ikatan Apoteker Indonesia Pengurus Cabang Surakarta \\ ${ }^{2}$ Program Studi Farmasi, Fakultas Matematikan dan Ilmu Pengetahuan Alam, Universitas Sebelas Maret \\ *E-mail: yenifarida@staff.uns.ac.id
}

Received: 3 Februari 2020; Accepted: 1 Juli 2020; Published: 6 Juli 2020

\begin{abstract}
Abstrak
Praktek swamedikasi telah banyak dilaporkan di berbagai negara maju maupun berkembang dan meningkat secara global sehingga potensial menimbulkan berbagai problem. WHO menekankan bahwa edukasi dan pengawasan dibutuhkan dalam praktek swamedikasi. Kementrian Kesehatan Indonesia telah mencanangkan program Gerakan Masyarakat Cerdas Menggunakan Obat (GeMaCerMat) untuk membentuk kesadaran dan pemahaman masyarakat terhadap penggunaan obat dengan benar. Penelitian ini bertujuan untuk menilai pengaruh sosialisasi GeMaCerMat terhadap pengetahuan dan perilaku masyarakat tentang penggunaan obat yang benar melalui pendekatan keluarga. Penelitian survey dilakukan dengan menggunakan instrument kuisioner dan wawancara responden. Responden adalah masyarakat di wilayah Kota Surakarta yang menjadi daerah binaan Agent of GeMaCerMat (AoC) yang ditetapkan dengan purposive sampling. Hasil penilaian pengetahuan sebelum dan sesudah sosialisasi GeMaCerMat dibandingkan dan dianalisis perbedaannya dengan uji t berpasangan. Dari 206 responden yang dilibatkan menunjukan hasil penilaian pengetahuan pada pretes menunjukkan rata-rata responden memiliki pengetahuan yang sangat kurang dengan nilai menjawab benar 52,48. Nilai postes menunjukan adanya kenaikan pengetahuan rata-rata responden menjadi 80,24 (baik). Hasil analisis SPSS dengan Kolmogorov Smirnov menunjukan data terdistribusi normal sehingga bisa dilakukan uji t berpasangan untuk menilai perbedaan nilai pretes dan postes. Sosialisasi GeMaCerMat berpengaruh terhadap pengetahuan responden yang dibuktikan dengan ada perbedaan signifikan antara rata-rata nilai pengetahuan sebelum (pretes) dan setelah (postes) $(\mathrm{p}=0,000$ $; \mathrm{p}<0,05)$. Penilaian perilaku menunjukan bahwa setelah sosialisasi rata-rata responden memiliki perilaku yang baik, ditunjukan dengan $89,02 \%$ responden menjawab benar dalam penerapan cara mendapatkan obat, menggunakan, menyimpan dan membuang obat dengan benar.
\end{abstract}

Kata Kunci: GeMaCerMat, pengetahuan, perilaku penggunaan obat, pendekatan keluarga

\section{Abstract}

Self-medication practices has been widely reported in various developed and developing countries which is increasing globally so that it may potentially causes various problems. WHO emphasized that education and supervision of self-medication practices are needed. The Indonesian Ministry of Health has launched the "GeMaCerMat" program to encourage public awareness and understanding of proper drug uses. This study aims to analyzed the effect of GeMaCerMat's socialization on community knowledge and behavior about the correct use of drugs through a family approach. Survey research was conducted using questionnaire instruments and interview respondents. Respondents are Surakarta's people in the fostered area of the Agent of GeMaCerMat (AoC) which is determined by purposive sampling. The results of the knowledge assessment before and after the intervention were compared and the differences were analyzed by paired t tests. Among 206 respondents involved, the results show that the average respondent has very less knowledge (52.48). Posttest value indicates an increase in knowledge of the average respondent to 80.24 (good). GeMaCerMat's socialization influenced peoples's knowledge that prooven by significant differences between pretest and postest $(P=0,000 ; P<0,05)$. Behavioral assessment shows that after socialization, the average respondent has good behavior (89.02\%) in applying how to get drugs, use, store and dispose of drugs properly. 


\section{PENDAHULUAN}

Praktek swamedikasi telah banyak dilaporkan di berbagai negara maju maupun berkembang dan meningkat secara global (Esan et al., 2018; Lukovic et al., 2014). Swamedikasi adalah upaya pengobatan yang dilakukan sendiri oleh masyarakat untuk mengatasi berbagai keluhan dan penyakit ringan seperti demam, nyeri, pusing, batuk, influenza, sakit maag, kecacingan, diare, penyakit kulit dan lain-lain. Swamedikasi merupakan salah satu cara untuk meningkatkan keterjangkauan pengobatan. (Depkes, 2007). Faktor-faktor yang mempengaruhi praktek swamedikasi antara lain usia, tingkat pendidikan, tidak jangkaunya layanan kesehatan, pengaruh iklan obat, dan kemudahan mendapatkan obat tanpa resep (Kassie et.al., 2018).

Akan tetapi, kurangnya pengetahuan dan pemahaman masyarakat tentang obat dan cara penggunaan obat dalam swamedikasi dapat menyebabkan problem antara lain mengaburkan tanda dan gejala penyakit sehingga bisa menyebabkan misdiagnosis, resistensi obat, dan penundaan penemuan penyakit. Dalam hal ini, WHO menekankan bahwa dibutuhkan edukasi dan pengawasan terhadap praktek swamedikasi (WHO, 1998).

Obat-obat bebas dan bebas terbatas yang dapat dibeli tanpa resep dokter mendorong semakin banyaknya perilaku pengobatan sendiri. Semakin banyak obat yang beredar di pasaran memberikan alternatif pilihan yang beragam. Pemilihan obat seringkali tidak didasarkan pada pertimbangan ilmiah, tetapi hanya pertimbangan kebiasaan atau saran dari orang lain. Hal ini dapat berpotensi menimbulkan bahaya, karena penggunaan obat yang tidak tepat dan berlebihan dapat memunculkan efek samping yang kadang tidak bisa dipredikasikan (Ruiz, 2010; Karimy et.al., 2019).

Pemerintah Indonesia melalui Kementrian Kesehatan telah mencanangkan program Gerakan Masyarakat Cerdas
Menggunakan Obat (GeMaCerMat) sesuai Keputusan Menteri Kesehatan RI HK.02.02/MENKES/427/2015. Gerakan ini merupakan kolaborasi antara pemerintah dan masyarakat yang diwujudkan dalam serangkaian kegiatan dalam rangka membentuk kepedulian, kesadaran, pemahaman dan keterampilan masyarakat dalam menggunakan obat secara tepat dan benar. Program ini telah diamanatkan sampai level pelayanan kesehatan primer yaitu Puskesmas (Kemenkes RI, 2016 ${ }^{\mathrm{b}}$ ).

GeMaCerMat dilaksanakan melalui 4 strategi yaitu:

1. Regulasi dan advokasi terkait GeMa CerMat dan Penggunaan Obat Rasional bagi tenaga kesehatan dan masyarakat, serta advokasi pada pemangku kepentingan terkait. 2. Komunikasi dan publikasi yang melibatkan media masa untuk menyebarluaskan informasi pada masyarakat dan penyebaran informasi pada masyarakat melalui media cetak, eletronik dan sosial media

3. Edukasi masyarakat sebagai upaya pemberian informasi untuk meningkatkan kesadaran dan pemahaman masyarakat untuk lebih bijak dalam menggunakan obat dengan dasar Program Indonesia Sehat Pendekatan Keluarga (PIS-PK). Hasil PIS-PK rata-rata pasien hipertensi belum berobat teratur (Kemenkes RI, 2016 ${ }^{\mathrm{a}}$ ).

4. Pemberdayaan masyarakat dalam telaah obat secara mandiri, masyarakat yang secara mandiri dapat berperan untuk mewujudkan masyakrat Indonesia yang sehat.

Adanya penelitian yang berbasis pendekatan sosialisasi dan wawancara diharapkan dapat mengarahkan masyarakat agar bijak dalam mendapatkan, menggunakan, menyimpan, dan membuang obat dengan tepat. Selanjutnya efek yang diinginkan adalah perubahan perilaku dan paradigma penggunaan obat tidak tepat yang selama ini diterapkan dikehidupan sehari hari. Luaran akhir dari program ini adalah 
masyarakat mampu menjadi agent of change penggunaan obat dengan tepat dimulai dari keluarga.

Penelitian ini dilakukan dengan tujuan untuk memperoleh gambaran pengetahuan dan perilaku masyarakat tentang penggunaan obat yang benar sebelum dan setelah mendapatkan intervensi kegiatan GeMaCerMat.

\section{METODE PENELITIAN Desain Penelitian}

Penelitian survey dilakukan dengan pengambilan data melalui wawancara dan kuisioner. Penelitian ini telah mendapatkan surat kelaikan etik dari Komisi Etik Penelitian Kesehatan FK Universitas Muhammadiyah Surakarta dengan no. 2515/B.2/KEPKFKUMS/XI/2019.

\section{Populasi dan Sampel}

Populasi dalam penelitian ini merupakan seluruh masyarakat di daerah binaan Puskesmas Pajang, Puskesmas Banyuanyar, Puskesmas Jayengan, Puskesmas Pucangsawit, Puskesmas Penumping, dan Puskesmas Gambirsari.

Teknik sampling yang dilakukan dalam penelitian ini adalah Purposive sampling dengan kriteria inklusi antara lain:

1. Masyarakat di daerah binaan Agent of GeMaCerMat (AoC) yang meliputi 6 kelurahan yaitu Kelurahan Sumber, Bumi, Tipes, Pajang, Pucangsawit dan Kadipiro.

2. Dapat membaca dan menulis.

3. Bersedia untuk terlibat dalam penelitian yang dibuktikan dengan informed consent.

\section{Teknik Pengumpulan Data}

Tahap persiapan

Konsolidasi dengan lintas sektoral dan lintas program untuk pelaksanaan program, tempat pelaksanaan program, serta pembuatan kuesioner dan uji validitas dan reliabilitas kuesioner pada 30 responden non sampel.

\section{Tahap pelaksanaan}

Kegiatan ini dilakukan pada bulan Oktober - November 2019. Tahap pelaksanaan terdiri dari penilaian awal pengetahuan (pretes), sosialisasi GeMaCerMat (intervensi) diberikan 1 kali dan penilaian hasil (postes) yang diberikan 2 minggu setelah intervensi. Kuesioner dibagikan kepada responden sebelum sosialisasi (pretes) dan setelah sosialisasi (postes) untuk menilai perubahan pengetahuan antara sebelum dan setelah dilakukan sosialisasi GeMaCerMat. Sosialisai dilakukan dengan metode CBIA (Cara Belajar Insan Aktif) yaitu dengan metode pembelajaran berkelompok yang mengaktifkan peserta (Kemenkes RI, 2015). Materi yang diberikan pada peserta meliputi Dagusibu dan 50 (nama dan kandungan obat, khasiat, dosis, cara penggunaan, dan efek samping obat.

Wawancara dilakukan dengan kunjungan ke rumah responden 2 minggu setelah intervensi untuk menilai perilaku responden setelah diberikan sosialisasi GeMaCerMat.

Tahap penyelesaian

Tahap ini terdiri dari analisis data, penyusunan laporan dan tindak lanjut. Pengetahuan diukur dari nilai kuesioner, yang di analisis menggunakan kategori penilaian (Artikunto 2010). Perubahan Perilaku diukur berdasarkan wawancara terstruktur menggunakan pedoman wawancara untuk menilai pemahaman responden terhadap implementasi GeMaCerMat.

\section{Instrumen Penelitian}

Instrumen penelitian ini adalah kuesioner yang telah teruji validitas dan reliabilitasnya serta panduan wawancara.

\section{Analisis Data}

1. Tabel dan Grafik demografi responden meliputi usia, jenis kelamin, tingkat pendidikan, dan pekerjaan

2. Tabel pengetahuan responden. Pengetahuan dan perilaku responden dihitung menggunakan Sekala Guttman, dengan nilai 0 pada jawaban salah dan 1 pada jawaban benar kemudian tiap skor responden dijumlahkan, dan jumlah maksimal adalah 10. Setelah itu dihitung persentase jumlah jawaban benar dan 
dimasukkan ke dalam kriteria objektif meliputi : 90-100\% kategori sangat baik, 80-89\% kategori baik, 70-79\% kategori cukup, 60-69\% kategori kurang dan $\leq 59$ $\%$ kategori sangat kurang.

3. Tabel perilaku responden, merupakan tabel yang menggambarkan persentase responden dengan perilaku benar berdasarkan hasil wawancara dan observasi langsung oleh peneliti

4. Nilai pengetahuan pre dan post test di analisis normalitasnya dengan uji Kolmogorov Smirnov, data yang terdistribusi normal memenuhi syarat untuk dilakukan uji parametrik dengan uji $\mathrm{t}$ berpasangan (Santoso, 2014).

\section{HASIL DAN PEMBAHASAN}

Responden yang dilibatkan dalam penelitian berjumlah 206 orang dengan pembagian wilayah yang dapat dilihat pada tabel 1 .

Tabel 1. Distribusi Responden berdasarkan wilayah

\begin{tabular}{lc}
\hline Wilayah & Jumlah \\
\hline Sumber & 37 \\
Bumi & 27 \\
Pajang & 41 \\
Tipes & 42 \\
Pucangsawit & 43 \\
Kadipiro & 16 \\
\hline
\end{tabular}

Karakteristik responden penelitian dapat dilihat pada tabel 2. Berdasarkan hasil tabel 2 menunjukkan bahwa responden didominasi oleh perempuan yaitu sebesar $91,75 \%$. Hal ini selaras dengan penelitian Widyawati (2019) yang menyatakan bahwa ibu memiliki peran besar dalam menjaga keluarga sehat, baik untuk lingkungan yang tinggal di perkotaan maupun di desa. Dalam penelitian ini, responden dalam penelitian ini menurut WHO 2018, masuk pada kategori usia dewasa (18 - 40 tahun) sampai dengan usia tua (41 65 tahun). Responden terbanyak adalah kategori usia tua yaitu 71,36 \%. Hal ini telah sesuai dengan profil data penduduk kota Surakarta yang menunjukan bahwa usia tua lebih banyak $(42,2 \%)$ dibandingkan usia dewasa (30,43\%). Dengan demikian, responden telah menggambarkan profil penduduk Surakarta.

Penggolongan tingkat pendidikan responden didasarkan pada Undang-Undang No. 20 Tahun 2003 tentang Sistem Pendidikan Nasional yang mengklasifikasikan Pendidikan menjadi: Pendidikan dasar/rendah (SD - SMP/MTs), Pendidikan menengah (SMA/SMK), dan Pendidikan tinggi (Diploma s.d Doktoral) sebagian besar responden berpendidikan dasar dan menengah. Hal ini telah sesuai dengan data profil kependudukan kota Surakarta yang menunjukan bahwa penduduknya sebagian besar memiliki Pendidikan terakhir SMA/SMK $(40,04 \%)$ diikuti oleh penduduk berpendidikan dasar/rendah $(39,3 \%)$.

Tabel 2. Karakteristik Responden Penelitian

\begin{tabular}{llcr}
\hline Variabel & & Jumlah (N=206) & Persentase \\
\hline Jenis Kelamin & Perempuan & 189 & $91,75 \%$ \\
& Laki - laki & 17 & $8.25 \%$ \\
\multirow{2}{*}{ Usia } & & & \\
& 18-40 tahun & 59 & $28,64 \%$ \\
& $>40$ tahun & 147 & $71,36 \%$ \\
Pendidikan & & & \\
& Dasar/rendah & 93 & $45,15 \%$ \\
& Menengah & 98 & $45,57 \%$ \\
& Tinggi & 15 & $7,28 \%$ \\
Pekerjaan & & 16 & $7,76 \%$ \\
& PNS/TNI/ POLRI & 87 & $42,24 \%$ \\
& Swasta/Wiraswasta & 103 & $50,00 \%$ \\
\hline
\end{tabular}


Tabel 3. Nilai pengetahuan responden pada pretes dan postes

\begin{tabular}{|c|c|c|c|c|c|}
\hline \multirow[t]{2}{*}{ No } & \multirow[t]{2}{*}{ Pertanyaan Kuesioner } & \multicolumn{2}{|c|}{ Pretes } & \multicolumn{2}{|c|}{ Postes } \\
\hline & & $\begin{array}{c}\text { Jawaban } \\
\text { benar }(\%)\end{array}$ & Kategori & $\begin{array}{c}\text { Jawaban } \\
\text { benar }(\%)\end{array}$ & Kategori \\
\hline 1 & $\begin{array}{l}\text { Selama ini apakah Saudara pernah } \\
\text { membeli obat di warung }\end{array}$ & 28,2 & $\begin{array}{l}\text { Sangat } \\
\text { Kurang }\end{array}$ & 68,45 & Kurang \\
\hline 2 & $\begin{array}{l}\text { Apa yang dimaksud kontraindikasi } \\
\text { obat }\end{array}$ & 33,0 & $\begin{array}{l}\text { Sangat } \\
\text { Kurang }\end{array}$ & 76,21 & Cukup \\
\hline 3 & $\begin{array}{l}\text { Apakah Saudara selalu membaca } \\
\text { petunjuk/informasi penggunaan obat } \\
\text { pada brosur/kemasan obat? }\end{array}$ & 97,6 & $\begin{array}{c}\text { Sangat } \\
\text { Baik }\end{array}$ & 98,06 & $\begin{array}{c}\text { Sangat } \\
\text { Baik }\end{array}$ \\
\hline 4 & Apa itu Efek samping obat & 28,2 & $\begin{array}{l}\text { Sangat } \\
\text { Kurang }\end{array}$ & 68,93 & Kurang \\
\hline 5 & $\begin{array}{l}\text { Apa yang Saudara lakukan jika } \\
\text { mendapat resep obat kimia dan } \\
\text { tradisional/fitofarmaka? }\end{array}$ & 66,0 & Kurang & 84,95 & Baik \\
\hline 6 & $\begin{array}{l}\text { Bagaimana aturan minum } \\
\text { antibiotik? }\end{array}$ & 74,8 & Cukup & 89,32 & Baik \\
\hline 7 & $\begin{array}{l}\text { Bagaimana cara Saudara mengetahui } \\
\text { bahwa obat yang ada di rumah } \\
\text { rusak? }\end{array}$ & 61,2 & Kurang & 82,52 & Baik \\
\hline 8 & $\begin{array}{l}\text { Bagaimana cara penyimpanan obat } \\
\text { di rumah yang benar? }\end{array}$ & 40,8 & $\begin{array}{l}\text { Sangat } \\
\text { Kurang }\end{array}$ & 75,24 & Cukup \\
\hline 9 & $\begin{array}{l}\text { Bagaimana Saudara membuang obat } \\
\text { yang sudah tidak digunakan/rusak? }\end{array}$ & 75,7 & Cukup & 91,26 & $\begin{array}{l}\text { Sangat } \\
\text { Baik }\end{array}$ \\
\hline 10 & $\begin{array}{l}\text { Apa arti obat di minum } 3 \times 1 \text { tablet } \\
\text { sehari? }\end{array}$ & 19,4 & $\begin{array}{l}\text { Sangat } \\
\text { Kurang }\end{array}$ & 67,48 & Kurang \\
\hline & Rata-rata & 52,48 & $\begin{array}{l}\text { Sangat } \\
\text { Kurang }\end{array}$ & 80,24 & Baik \\
\hline
\end{tabular}

Menurut Dahlan (2014), validitas berhubungan dengan suatu peubah mengukur apa yang seharusnya diukur. Uji validitas digunakan untuk mengukur sah, atau valid tidaknya suatu kuesioner. Suatu kuesioner dikatakan valid jika pertanyaan pada kuesioner mampu untuk mengungkapkan sesuatu yang akan diukur oleh kuesioner tersebut.

Uji validitas dan reliabilitas kuesioner dilakukan pada 30 responden. Hasil uji validitas menunjukan bahwa koefisien validitas instrument bernilai $>\mathrm{r}$ table $(0,361)$ artinya setiap item pertanyaan valid. Uji reliabilitas kuesioner didapatkan nilai Cronbach's Alpha 0,603 artinya kuesioner dapat digunakan untuk melakukan penelitian karena memiliki tingkat reliabilitas pada rentang moderat $(0,50-0,70)$ (Dahlan, 2014).

Pengetahuan responden diukur dengan kuisioner yang terdiri dari 10 item pertanyaan yang bersifat terbuka yang disusun berdasarkan buku saku GeMaCerMat. Pengetahuan yang diukur meliputi cara mendapatkan obat (no.1 dan 5), kontraindikasi (no.2), cara penggunaan obat (no. 3, 6,10), efek samping (no.4) dan penyimpanan obat (no.7-9). Hasil pre test dan post test dapat dilihat pada tabel 3.

Berdasarkan tabel 3 dapat dinilai pengetahuan responden berdasarkan jawaban benar dari kuisioner. Hasil pengukuran pengetahuan pada pretes menunjukan secara keseluruhan responden memiliki pengetahuan yang sangat kurang ditunjukan dengan nilai jawaban benar 52,48 . Nilai pengetahuan yang cukup baik diketahui oleh responden adalah cara minum antibiotik dengan 74,8 dan cara membuang obat dengan nilai 75,7.

Pada postes menunjukan adanya kenaikan yang cukup signifikan pada pengetahuan rata-rata responden dari nilai 
Tabel 4. Nilai Perilaku responden berdasarkan wawancara

\begin{tabular}{lcccc}
\hline Uraian Panduan Wawancara & $\begin{array}{c}\text { Persentase } \\
\text { Responden } \\
\text { menjawab } \\
\text { Benar }\end{array}$ & Kategori & $\begin{array}{c}\text { Persentase } \\
\text { Jawaban } \\
\text { Salah }\end{array}$ & $\begin{array}{c}\text { Persentase } \\
\text { Tidak } \\
\text { menjawab }\end{array}$ \\
\hline $\begin{array}{l}\text { Bagaimana Saudara mendapatkan obat } \\
\text { selama 2 minggu ini? }\end{array}$ & 87,35 & Baik & 5,72 & 6,93 \\
\hline $\begin{array}{l}\text { Bagaimana selama 2 minggu ini } \\
\text { responden menggunakan obat simptom } \\
\text { dan antibiotik? }\end{array}$ & 88,77 & Baik & 4,07 & 7,15 \\
\hline $\begin{array}{l}\text { Bagaimana selama 2 minggu ini } \\
\text { responden menyimpan obat tablet ? }\end{array}$ & 94,15 & Sangat & 0,81 & 5,04 \\
\hline $\begin{array}{l}\text { Berapa lama obat syrup (encer/ tidak } \\
\text { kental) dapat digunakan setelah } \\
\text { dibuka? }\end{array}$ & 86,18 & Baik & 3,23 & 10,59 \\
\hline $\begin{array}{l}\text { Amati cara membuang obat oleh } \\
\text { responden? }\end{array}$ & 88,65 & Baik & 2,45 & 8,90 \\
\hline Rata-rata & $\mathbf{8 9 , 0 2}$ & Baik & $\mathbf{3 , 2 6}$ & $\mathbf{7 , 7 2}$ \\
\hline
\end{tabular}

52,48 menjadi 80,24 sehingga dapat dikategorikan pengetahuannya baik. Hal ini didukung oleh hasil analisis SPSS dengan uji $\mathrm{t}$ berpasangan yang menunjukan signifikansi $0,000(\mathrm{p}<0,05)$ artinya ada perbedaan ratarata antara nilai jawaban benar sebelum intervensi (prestest) dan setelah intervensi (post test). Hal ini dapat dikatakan bahwa pembelajaran atau sosialisasi kepada masyarakat di daerah binaan dapat meningkatkan pengetahuan dari responden mengenai GeMaCerMat. Adanya informasi baru mengenai suatu hal memberikan landasan kognitif baru bagi terbentuknya pengetahuan terhadap hal tersebut (Budiman dan Riyanto, 2013).

Diantara beberapa domain pengetahuan, cara memperoleh obat, efek samping obat dan aturan minum obat masih tergolong kategori kurang atau sangat kurang. Terkait dengan cara memperoleh obat, masih banyak masyarakat yang tidak mengetahui bahwa membeli obat sebaiknya di apotek atau toko obat berijin. Hal ini disebabkan karena kemudahan masyarakat dalam memperoleh obat di warung-warung atau toko kelontong yang tidak berijin menjual obat.

Cara memperoleh obat terkait dengan informasi obat yang diberikan sehingga ini berhubungan dengan aturan minum obat dan risiko efek samping obat. Banyak orang yang tidak menyadari bahwa reaksi yang dirasakan merupakan suatu efek samping obat. Hal tersebut diasumsikan sebagai salah satu bentuk ketidakwaspadaan reponden terhadap efek samping dari obat yang digunakannya (Hermawati, 2012). Seorang pelaku swamedikasi seharusnya mengetahui efek samping obat yang digunakan sehingga dapat memperkirakan apakah suatu keluhan yang timbul kemudian merupakan suatu penyakit baru atau efek samping obat. Dengan begitu, mereka dapat segera menanggulanginya jika ternyata efek tersebut merugikan diri mereka (Depkes RI, 2007).

Pemberian informasi akan meningkatkan pengetahuan seseorang. Pengetahuan dapat menjadikan seseorang memiliki kesadaran untuk berperilaku sesuai pengetahuan yang dimiliki. Perubahan perilaku yang dilandasi pengetahuan, kesadaran dan sikap yang positif bersifat lebih permanen karena didasari oleh kesadaran bukan paksaan (Notoatmodjo, 2011). Dalam penelitian ini, selain pengetahuan juga dinilai perilaku responden . Dengan harapan bahwa peningkatan pengetahuan akan dapat mengarahkan pada perilaku yang benar tentang penggunaan obat. 
Perilaku yang dinilai pada responden meliputi cara mendapatkan obat, cara mendapatkan obat, cara menyimpan obat dan membuang obat. Dari tabel 4 diketahuai bahwa rata-rata perilaku responden dalam kategori baik. Akan tetapi, masih ada responden yang masih menunjukan perilaku salah tentang cara mendapatkan obat yaitu masih banyak responden yang tetap membeli obat di warung. Menurut Notoatmodjo (2011) perilaku seseorang tentang kesehatan tidak hanya dipengaruhi oleh pengetahuan seseorang akan tetapi ada faktor lain yaitu kepercayaan, keyakinan, budaya, tradisi dan sebagainya.

Karakteristik responden berkaitan erat dengan tingkat pengetahuan. Ada beberapa faktor yang dapat mempengaruhi tingkat pengetahuan anatar lain pendidikan, umur, lingkungan dan sosial budaya. Semakin tinggi tingkat pendidikan dan status sosial seseorang maka tingkat pengetahuannya akan semakin tinggi . Demikian halnya dengan umur, semakin bertambahnya umur seseorang maka pengetahuannya juga semakin bertambah (Wawan, 2010). Kelemahan pada penelitian ini adalah tidak menganalisis pengaruh faktor karakteristik responden terhadap pengetahuan dan perilaku.

\section{KESIMPULAN}

Sosialisasi GeMaCerMat berpengaruh terhadap pengetahuan responden yang dibuktikan dengan ada perbedaan signifikan antara rata-rata nilai pengetahuan sebelum (pretes) dan setelah (postes) $(p=0,000 ; p<$ $0,05)$.

Penilaian perilaku menunjukan bahwa setelah sosialisasi rata-rata responden memiliki perilaku yang baik, ditunjukan dengan $89,02 \%$ responden menjawab benar dalam penerapan cara mendapatkan obat, menggunakan, menyimpan dan membuang obat dengan benar.

\section{Daftar Pustaka}

Arikunto, S. 2010. Prosedur Penelitian Suatu Pendekatan Praktik. Jakarta: Rineka Cipta.

Budiman dan Riyanto, A. 2013. Kapita Selekta Kuesioner Pengetahuan dan Sikap Dalam

Penelitian Kesehatan. Jakarta: Salemba Medika

Depkes, 2007, Pedoman Penggunaan Obat Bebas dan Obat Bebas Terbatas, Jakarta, Kementrian Kesehatan Republik Indonesia

Dahlan, Sopiyudin, 2014. Statistika untuk Kedokteran dan Kesehatan Edisi 6, Jakarta: Salemba Medika.

Esan DT., Fasoro AA., Odesanya OE., Esan TO., Ojo EF., Faeji CF., 2018. Assessment of SelfMedication Practices and Its Associated Factors among Undergraduates of a Private University in Nigeria. J Environ Public Health. 2018; 2018: 5439079. doi: $10.1155 / 2018 / 5439079$

Hermawati, D. 2012. Pengaruh Edukasi Terhadap Tingkat Pengetahuan dan Rasionalitas Penggunaan Obat Swamedikasi Pengunjung di Dua Apotek Kecamatan Cimanggis, Depok. Skripsi. Fakultas Matematika dan Ilmu Pengetahuan Alam Program Studi Farmasi UI.

Karimy M., Rezaee-Momtaz, M., Tavousi M., Montazeri A., Araban M., 2019. Risk factors associated with self-medication among women in Iran. BMC Public Health 19, 1033 (2019). https://doi.org/10.1186/s12889-019-7302-3 
Kassie, AD., Biftu, SS., Mekkonen, HS. 2018. Self-medication practice and associated factors among adult household members in Meket district, Northeast Ethiopia, 2017. BMC Pharmacol Toxicol. 2018 Apr 10;19(1):15. doi: 10.1186/s40360-018-0205-6

Kemenkes RI, 2015, Keputusan Menteri Kesehatan nomor HK.02.02/MENKES/427/2015, Gerakan Masyarakat Cerdas Menggunakan Obat, Jakarta, Kementrian Kesehatan Republik Indonesia

Kemenkes RI, 2016 , Peraturan Menteri Kesehatan Republik Indonesia, Nomor 39 Tahun 2016, Pedoman Penyelenggaraan Program Indonesia Sehat dengan Pendekatan Keluarga, Jakarta, Kementrian Kesehatan Republik Indonesia

Kemenkes RI, 2016 ${ }^{\mathrm{b}}$, Peraturan Menteri Kesehatan Republik Indonesia, Nomor 74 Tahun 2016, Standar Pelayanan Kefarmasian Di Puskesmas, Pasal 1 Poin 5, Jakarta, Kementrian Kesehatan Republik Indonesia

Lukovic JA, Miletic V, Pekmezovic T, Trajkovic G, Ratkovic N, Aleksic D, Grgurevic A. 2014. Self-medication practices and risk factors for self-medication among medical students in Belgrade, Serbia. PLoS One. 2014 Dec 11;9(12):e114644. doi: 10.1371/journal.pone.0114644

Notoatmodjo, S. 2011. Kesehatan Masyarakat. Jakarta: Rineka Cipta

Ruiz, E. Maria., 2010. Risks of Self-Medication Practices. Curr Drug Saf. 2010 Oct;5(4):31523. doi: $10.2174 / 157488610792245966$

Santoso, Singgih. 2014. Statistik Multivariat Edisi Revisi. Jakarta: PT Elex Media Komputindo.

Wawan, A. 2010. Teori dan Pengukuran Pengetahuan, Sikap dan Perilaku Manusia.Yogyakarta : Nuha Medika

Widyawati, 2019. Peran Ibu Tentukan Kesehatan Keluarga. Biro Komunikasi dan Pelayanan Masyarakat. Kementrian Kesehatan RI. Diakses 02 Juli 2020 di http://sehatnegeriku.kemkes.go.id

World Health Organization, 1998 "The role of the pharmacist in self-care and self-medication," Report of the 4th WHO consultative group on the role of the pharmacist, World Health Organization, Hague, Netherlands 